\title{
Robust optimization in production engineering - methods and application
}

\author{
Adrian Knapczyk ${ }^{1, *}$, Stawomir Francik ${ }^{1}$, Marcin Jewiarz ${ }^{1}$, Krzysztof Mudryk $^{1}$, \\ and Marek Wróbel ${ }^{1}$ \\ ${ }^{1}$ University of Agriculture in Krakow, Faculty of Production and Power Engineering, Department of \\ Mechanical Engineering and Agrophysics, Balicka 120, 30-149 Krakow, Poland
}

\begin{abstract}
Methods that use robust optimization are aimed at finding robustness to decision uncertainty. Uncertainty may affect the input parameters (problem) and the final solution. Robust optimization is applicable in many areas, such as: operational research, IT, energy, production engineering and others. The aim of the work was to indicate the main methods and examples of applications of robust optimization in the area of production engineering. Documents (articles and proceedings paper) indexed in the Web of Science - Core Collection database (WoSCC) from 2014-2018 were used for analysis. The search has been limited to the WoS-CC category: Engineering Industrial and Engineering Manufacturing. The main areas of application were: the scheduling of projects and tasks, production planning, and risk management. The most common methods were: linear programming, evolutionary algorithms, mixed integer programming, dynamic programming and many others.
\end{abstract}

\section{Introduction}

Robust Optimization (RO) is a modern modeling methodology that is combined with various computational tools. It is used for modeling and optimization of processes, with high data uncertainty [1]. This methodology takes into account the uncertainties arising at various stages (Fig. 1) (uncertainty of data, environment, etc.). The model also analyzes the uncertainty of the results and optimizes it to obtain a result that fits within the objective function and meets the assumed optimality criteria.

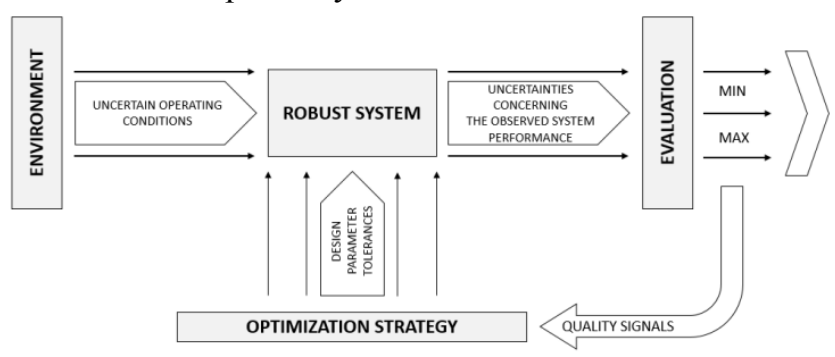

\footnotetext{
* Corresponding author: adrian.knapczyk@urk.edu.pl
} 
Fig. 1. Diagram of robust system. (Based on [2])

$\mathrm{RO}$ is used in many areas, such as: IT, energy, economics, project management, production engineering and many more. In particular, the production area is a challenge for RO.

Contemporary production is characterized by high complexity of production processes. This is a serious challenge, for example when creating a production schedule. Enterprises produce a wide range of products. Different technologies use machines with varying capacities, and this directly affects production times. One of the main problems when planning production is the high uncertainty regarding the terms of the schedule - not all production tasks are known at the beginning of the planning process. They may appear after the scheduling, which necessitates its correction. All this leads to difficulties in coordinating production in time [3-5]. Modern industry successfully uses various methods of scheduling tasks in the production scheduling process [6]. Therefore, it is reasonable to look for new algorithms, methods and systems supporting RO. This work analyzes the scientific achievements in the area of RO production engineering. The bibliometric analysis (quantitative and qualitative) was used for this purpose.

Bibliometric analysis allows to perform objectively analyzes of publications, organizations, achievements of scientists and others. These analyzes are based on statistical quantitative analyzes of data from global scientific publication databases (Web of Science, Scopus and others). Bibliometric analysis allows to indicate trends, main research topics in a selected topic, discipline and other

\section{Aim of the study}

The aim of the work was to review selected methods and applications of RO in the area of production engineering. To achieve the goal, the current state of research was identified and the main research topics, decision problems and tools used were identified.

\section{Materials and Methods}

The methodology proposed by Knapczyk et. al. [7, 8], using elements of bibliometric techniques:

1.. Creation of a set of documents based on searching for indexed items in the Web of Science - Core Collection (WoS-CC) database for search: TOPIC: ("robust optimization") in Web of Science Categories: "Engineering Industrial" and "Engineering Manufacturing". The search was carried out from 2014 to 2018 documents in English.

2. Uploading all publications of the selected journal in the analysed period of time and extracting bibliometric data (authors, title, year of issue, key words, additional key words, publishing house).

3. Construction and analysis of term maps (VOSviewer software).

4. Quantitative analysis of the set of documents created in the aspect of: number of publications and number of citations, major countries.

5. Qualitative analysis for documents in last year. The analysis of the content of documents in terms of:

- decision problem,

- area of application,

- used type of method / algorithm / framework to RO.

VOS viewer is a free program that is used by researchers for bibliometric analysis. In this work, the program was used to create a map of terms (years of publication). 


\section{Results}

Bibliometric quantitative analysis

In the examined period, 241 documents were analysed in total (according to WoS-CC database).

The authors come from China (60 documents), Iran (50 documents), China (47 dokuments), USA (50 documents) and France (18 documents).

The most-cited publications include:

- Ho W. et. al. (2015) - Total Citation: 146 [9],

- $\quad$ Scott J. et. al. (2015) - Total Citation: 50 [10],

- Vahdani B. and Mohammadi M. (2015) - Total Citation: 41 [11].

In the next stage, the most frequently occurring key words were determined for the analysed periods. For each period the analysis of all key words Author Keywords was performed (VOSviewer). The analysis was limited to the key words which occurred minimum 2 times. Results of the simulations are presented in Fig. 2.

Fig. 2 presents a map of terms showing connections between key words in the years (2014-2018). The colors refer to specific years. In 2014 (dark blue) the main research topics were: "finite element simulations", "uncertain processing time". In 2015 (light blue) „flow shop”, „optimization”, „robust design”, „multi-floor layout problem”, „, mixed integer programming”, ,,memetic algorithm”, ,line balancing”, “decision support system”. In 2016 (green): "robust optimization”, "robustness", "multi-criteria”, "uncertainty", „scheduling”, „single machine" supply chain”, "supply chain management”, „facility location”, „,incomplete information”, ,interval uncertainty”, „,benders decomposition”, „branch and cut". In 2017 (yellow): "stochastic programming", "inventory", "project scheduling", "production planning", "genetic algorithm". In the last year (2018 - orange and red) research topics such as: "two-stage robust optimization", "energy storage”, „energy market”, "constructive heuristic”, ,production”, „lagrargian relasation”, ,,agregator” and „demand response". Analyzing these keywords, one can notice the transition from the mathematical approach (describing the problem and matching the appropriate methods / algortim), by optimizing production (schedules, stocks), and ending with project management and energy management. 

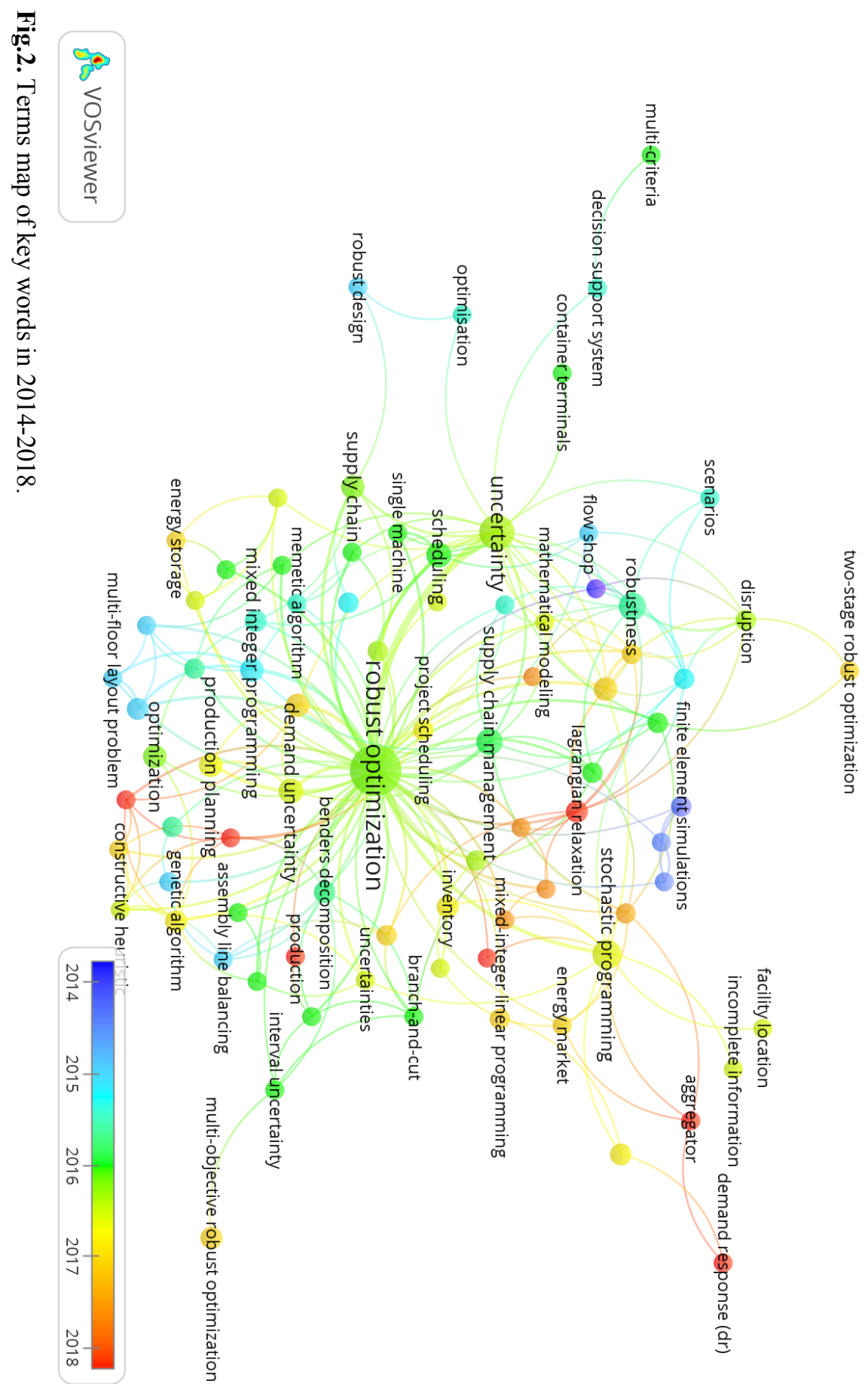


\section{Bibliometric qualitative analysis}

A detailed analysis of documents from the last year (2018) - 49 documents was carried out. The result of the analysis were selected decision problems along with the methods / algorithms and programs used in robust optimization. Selected documents are divided into the following thematic groups (Tab. 1): production (14 documents), logistics (13 documents), energy ( 5 documents), economics ( 2 documents), project management ( 2 documents), mathematical modeling ( 3 documents) and others (10 documents).

In publications belonging to particular groups, the following topics were raised (Tab.1.):

- Production: optimization of process parameters, scheduling of production plans, optimization of production stocks, selection of machine park,

- Logistics: supply chain, warehouse optimization, transport optimization,

- Power industry: optimization of energy management, scheduling of electricity supply processes, smart grid systems,

- Economics: issues related to investment costs,

- Project management: scheduling the implementation of operations in projects,

- Mathematical modeling: selection of new methods of RO,

- Other: scheduling in healthcare, scheduling in aviation, scheduling in Internet networks.

Table 1. Selected decision problems together with the methods used RO (2018 year).

\begin{tabular}{|c|c|c|}
\hline $\begin{array}{l}\text { Theme } \\
\text { groups }\end{array}$ & Decision problem & $\begin{array}{l}\text { Method / algorithm / framework to } \\
\text { robust optimization }\end{array}$ \\
\hline \multirow[t]{9}{*}{ Production } & $\begin{array}{l}\text { - A novel Robust optimization (RO) } \\
\text { approach to deal with the tolerance } \\
\text { optimization problem for the internal } \\
\text { combustion engine (ICEs) under } \\
\text { parameter and model uncertainties } \\
{[12]}\end{array}$ & - the Gaussian process models [12] \\
\hline & $\begin{array}{l}\text { - A VP-NCS chart for joint } \\
\text { monitoring mean and variability in } \\
\text { series systems under maintenance } \\
\text { policy [13] }\end{array}$ & $\begin{array}{l}\text { - Particle Swarm Optimization (PSO) } \\
\text { Algorithm [13] }\end{array}$ \\
\hline & $\begin{array}{l}\text { - Automation and robotics in the } \\
\text { slaughterhouse [14] }\end{array}$ & - the optimization method RBFopt [14] \\
\hline & $\begin{array}{l}\text { - Aggregate planning with Flexibility } \\
\text { Requirements Profile [15] }\end{array}$ & $\begin{array}{l}\text { - Mixed-Integer Linear Programming } \\
\text { (MILP) [15] }\end{array}$ \\
\hline & $\begin{array}{l}\text { - Lot-sizing and scheduling problem } \\
\text { under multistage demand uncertainty } \\
{[16]}\end{array}$ & - a Monte Carlo simulation [16] \\
\hline & $\begin{array}{l}\text { - The multi-objective robust } \\
\text { optimization of the billet are } \\
\text { performed based on 3D finite element } \\
\text { simulation [17] }\end{array}$ & $\begin{array}{l}\text { - Non dominated sorting genetic } \\
\text { algorithm (NSGA-II) [17] }\end{array}$ \\
\hline & $\begin{array}{l}\text { - A No Speeds and Coefficients PSO } \\
\text { approach to reliability optimization } \\
\text { problems [18] }\end{array}$ & $\begin{array}{l}\text { - No Speeds and Coefficients Particle } \\
\text { Swarm Optimization (NSC-PSO) [18] }\end{array}$ \\
\hline & $\begin{array}{l}\text { - Optimizing make-to-stock policies } \\
\text { [19] }\end{array}$ & $\begin{array}{l}\text { - Mixed-Integer Linear Programming } \\
\text { (MILP) [19] }\end{array}$ \\
\hline & $\begin{array}{l}\text { - The assembly line worker } \\
\text { assignment and balancing problem } \\
\text { (ALWABP) [20] }\end{array}$ & - Min-max regret $[20]$ \\
\hline
\end{tabular}




\begin{tabular}{|c|c|c|}
\hline & $\begin{array}{l}\text { - The problem of scheduling jobs with } \\
\text { interval uncertain due-dates is } \\
\text { considered with the objective to } \\
\text { minimize the total weight of late jobs, } \\
\text { utilizing the min-max regret approach } \\
\text { for computing robust solutions [21] }\end{array}$ & $\begin{array}{l}\text { - Mixed-Integer Linear Programming } \\
\text { (MILP) [21] } \\
\text { - min-max regret [21] }\end{array}$ \\
\hline & $\begin{array}{l}\text { - An integrated business continuity } \\
\text { and disaster recovery planning } \\
\text { (IBCDRP) model to build } \\
\text { organizational resilience [22] }\end{array}$ & - Multi-Objective Programming [22] \\
\hline & $\begin{array}{l}\text { - Production planning with order } \\
\text { acceptance and demand uncertainty } \\
\text { [23] }\end{array}$ & $\begin{array}{l}\text { - Mixed-Integer Linear Programming } \\
\text { (MILP) [23] }\end{array}$ \\
\hline & $\begin{array}{l}\text { - A hybrid approach integrating a } \\
\text { particle swarm optimization } \\
\text { algorithm with a Cauchy distribution } \\
\text { and genetic operators (HPSO+GA) } \\
\text { for solving an flexible job-shop } \\
\text { scheduling [24] }\end{array}$ & $\begin{array}{l}\text { - Particle Swarm Optimization (PSO) } \\
\text { Algorithm [24] } \\
\text { - Cauchy Distribution and Genetic } \\
\text { Operators (HPSO+GA) [24] }\end{array}$ \\
\hline & $\begin{array}{l}\text { - The robust machine availability } \\
\text { problem in a parallel machine } \\
\text { environment [25] }\end{array}$ & - Branch and Price Procedure [25] \\
\hline \multirow[t]{8}{*}{ Logistics } & $\begin{array}{l}\text { - Supply chain planning through } \\
\text { exploring various uncertainty } \\
\text { situations and problems, sustainability } \\
\text { assessment, vendor selection, risk } \\
\text { mitigation, retail supply chain } \\
\text { planning, and supply chain } \\
\text { coordination [26] }\end{array}$ & - Stochastic Programming [26] \\
\hline & $\begin{array}{l}\text { - The comprehensive tactical planning } \\
\text { of supply chains under demand and } \\
\text { supply uncertainty [27] }\end{array}$ & - Stochastic Programming [27] \\
\hline & $\begin{array}{l}\text { - Supply chain network design } \\
\text { problem [28] }\end{array}$ & $\begin{array}{l}\text { - Lagrangian Relaxation Technique } \\
\text { [28] }\end{array}$ \\
\hline & $\begin{array}{l}\text { - A hybrid strategy that uses both } \\
\text { process flexibility and finished goods } \\
\text { inventory for supply chain risk } \\
\text { mitigation [29] }\end{array}$ & - (meta-) heuristics [29] \\
\hline & $\begin{array}{l}\text { - Sustainability in designing a blood } \\
\text { supply chain network [30] }\end{array}$ & $\begin{array}{l}\text { - Mixed-Integer Linear Programming } \\
\text { (MILP) [30] } \\
\text { - the Lagrangian relaxation technique } \\
{[30]}\end{array}$ \\
\hline & $\begin{array}{l}\text { - The multi-factory milk run pickup } \\
\text { problem with uncertain demand and } \\
\text { frequency (MFMRPP-UDF) [31] }\end{array}$ & $\begin{array}{l}\text { - adaptive genetic algorithm [31] } \\
\text { - Mixed-Integer Linear Programming } \\
\text { (MILP) [31] } \\
\text { - a general hybrid heuristic algorithm } \\
\text { [31] }\end{array}$ \\
\hline & $\begin{array}{l}\text { - The vehicle routing problem with } \\
\text { hard time windows under demand and } \\
\text { travel time uncertainty [32] }\end{array}$ & $\begin{array}{l}\text { - Adaptive Variable Neighborhood } \\
\text { Search [32] }\end{array}$ \\
\hline & $\begin{array}{l}\text { - Flexible and Robust Inventory- } \\
\text { Routing (FRIR) where a blood center } \\
\text { distributes the blood type of red blood } \\
\text { cell to hospitals under uncertain } \\
\text { demand and supply [33] }\end{array}$ & $\begin{array}{l}\text { - Adaptive Large Neighborhood Search } \\
\text { Heuristic (ALNS) algorithm [33] }\end{array}$ \\
\hline
\end{tabular}




\begin{tabular}{|c|c|c|}
\hline & $\begin{array}{l}\text { - A stochastic robust optimization } \\
\text { model for the design of a closed-loop } \\
\text { supply chain network [34] }\end{array}$ & $\begin{array}{l}\text { - Lagrangian Relaxation Technique } \\
\text { [34] }\end{array}$ \\
\hline & $\begin{array}{l}\text { - A multi-commodity multi-period } \\
\text { optimization model to analyse market } \\
\text { demand disruption risk in } \\
\text { agribusiness supply chains [35] }\end{array}$ & $\begin{array}{l}\text { - Two-Stage Stochastic Network-Based } \\
\text { Model [35] }\end{array}$ \\
\hline & $\begin{array}{l}\text { - A new robust multi-objective multi- } \\
\text { period model for supply chain } \\
\text { planning under uncertainty } \\
\text { considering quantity discounts [36] }\end{array}$ & $\begin{array}{l}\text { - Single-Objective Mixed-Integer } \\
\text { Programming Model [36] }\end{array}$ \\
\hline & $\begin{array}{l}\text { - Optimization the decisions of } \\
\text { facility location, emergency inventory } \\
\text { pre-positioning, and relief delivery } \\
\text { operations within a single-commodity } \\
\text { disaster relief network [37] }\end{array}$ & - Min-Max Robust Optimization [37] \\
\hline & $\begin{array}{l}\text { - The intermodal freight network } \\
\text { expansion problem consisting of } \\
\text { multiple periods [38] }\end{array}$ & $\begin{array}{l}\text { - Hybrid Simulated Annealing (SA) } \\
\text { Algorithm [38] }\end{array}$ \\
\hline $\begin{array}{l}\text { Project } \\
\text { management }\end{array}$ & $\begin{array}{l}\text { - The robust resource-constrained } \\
\text { project scheduling problem [39] }\end{array}$ & $\begin{array}{l}\text { - Mixed-Integer Linear Programming } \\
\text { (MILP) [39] }\end{array}$ \\
\hline & $\begin{array}{l}\text { - The robust resource-constrained } \\
\text { project scheduling problem (RCPSP) } \\
\text { with discrete time/resource trade-offs } \\
{[40]}\end{array}$ & - Monte Carlo Simulation [40] \\
\hline
\end{tabular}

\section{Conclusions}

1. Bibliometric analysis showed that the authors addressed such topics as: production optimization (task scheduling, production inventory management), logistics (supply chain), project management and energy management, mathematical modeling of selected decision problems.

2. It has been shown that the RO methodology uses algorithms, methods and calculation tools of very different levels of advancement.

\section{Acknowledgements}

This research was financed by the Ministry of Science and Higher Education of the Republic of Poland (Faculty of Production and Power Engineering, University of Agriculture in Krakow).

\section{References}

1. A. Ben-Tal and A. Nemirovski, Math. Program. 92, 453 (2002).

2. H.-G. Beyer and B. Sendhoff, Comput. Methods Appl. Mech. Eng. 196, 3190 (2007).

3. R. Tavakkoli-Moghaddam, F. Jolai, and F. Vaziri, Appl. Math. Comput. 170, 185 (2005).

4. R. Tavakkoli-Moghaddam, F. Taheri, and M. Bazzazi, SID 21, 269 (2008).

5. R. Pedarsani, J. Walrand, and Y. Zhong, Adv. Appl. Probab. 49, 603 (2017).

6. A. Knapczyk, S. Francik, and Z. Slipek, Contemp. Res. Trends Agric. Eng. (2018).

7. A. Knapczyk, S. Francik, N. Pedryc, and T. Hebda, 17th Int. Sci. Conf. Eng. Rural Dev. 
700 (2018).

8. A. Knapczyk, S. Francik, J. Fraczek, and Z. Slipek, 18th Int. Sci. Conf. Eng. Rural Dev. 18, 1503 (2019).

9. W. Ho, T. Zheng, H. Yildiz, and S. Talluri, Int. J. Prod. Res. 53, 5031 (2015).

10. J. Scott, W. Ho, P. K. Dey, and S. Talluri, Int. J. Prod. Econ. 166, 226 (2015).

11. B. Vahdani and M. Mohammadi, Int. J. Prod. Econ. 170, 67 (2015).

12. Y. Zhang and M. Li, J. Comput. Inf. Sci. Eng. 18, 041011 (2018).

13. A. Salmasnia, M. Namdar, and M. Noroozi, Comput. Ind. Eng. 124, 220 (2018).

14. T. Bo Jørgensen, A. Wolniakowski, H. G. Petersen, K. Debrabant, and N. Krüger, Robot. Comput. Integr. Manuf. 53, 162 (2018).

15. E. Demirel, E. C. Özelkan, and C. Lim, Int. J. Prod. Econ. 202, 45 (2018).

16. E. Curcio, P. Amorim, Q. Zhang, and B. Almada-Lobo, Int. J. Prod. Econ. 202, 81 (2018).

17. K. Wei, X. Fan, M. Zhan, X. Zeng, and X. Jiang, Int. J. Adv. Manuf. Technol. 97, 1165 (2018).

18. G. Anescu and A. P. Ulmeanu, Comput. Ind. Eng. 120, 31 (2018).

19. A. Agra, M. Poss, and M. Santos, Int. J. Prod. Econ. 200, 302 (2018).

20. J. Pereira, Comput. Oper. Res. 93, 27 (2018).

21. M. Drwal, Comput. Oper. Res. 91, 13 (2018).

22. N. Sahebjamnia, S. A. Torabi, and S. A. Mansouri, Int. J. Prod. Econ. 197, 63 (2018).

23. T. Aouam, K. Geryl, K. Kumar, and N. Brahimi, Comput. Oper. Res. 91, 145 (2018).

24. T. Jamrus, C.-F. Chien, M. Gen, and K. Sethanan, IEEE Trans. Semicond. Manuf. 31, 32 (2018).

25. G. Song, D. Kowalczyk, and R. Leus, IISE Trans. 50, 997 (2018).

26. K. Govindan and T. C. E. Cheng, Comput. Oper. Res. 100, 262 (2018).

27. A. Megahed and M. Goetschalckx, Comput. Oper. Res. 100, 287 (2018).

28. S. H. Alavi and A. Jabbarzadeh, Comput. Ind. Eng. 125, 69 (2018).

29. D. Simchi-Levi, H. Wang, and Y. Wei, Prod. Oper. Manag. 27, 1476 (2018).

30. H. Heidari-Fathian and S. H. R. Pasandideh, Comput. Ind. Eng. 122, 95 (2018).

31. Q. Wu, X. Wang, Y. D. He, J. Xuan, and W. D. He, Adv. Prod. Eng. Manag. 13, 169 (2018).

32. C. Hu, J. Lu, X. Liu, and G. Zhang, Comput. Oper. Res. 94, 139 (2018).

33. F. Jafarkhan and S. Yaghoubi, Comput. Ind. Eng. 117, 191 (2018).

34. A. Jabbarzadeh, M. Haughton, and A. Khosrojerdi, Comput. Ind. Eng. 116, 178 (2018).

35. G. Behzadi, M. J. O’Sullivan, T. L. Olsen, and A. Zhang, Int. J. Prod. Res. 56, 3524 (2018). 
36. E. Rahimi, M. M. Paydar, I. Mahdavi, J. Jouzdani, and A. Arabsheybani, J. Ind. Prod. Eng. 35, 214 (2018).

37. W. Ni, J. Shu, and M. Song, Prod. Oper. Manag. 27, 160 (2018).

38. F. Fotuhi and N. Huynh, Comput. Ind. Eng. 115, 138 (2018).

39. M. E. Bruni, L. Di Puglia Pugliese, P. Beraldi, and F. Guerriero, Comput. Oper. Res. 99, 178 (2018).

40. Z. Zhang and X. Zhong, J. Ind. Prod. Eng. 35, 243 (2018). 